\title{
INSTAGRAM AS MEDIUM OF PROMOTING ENGLISH SPEAKING SKILL: ENGLISH EDUPRENEURSHIP
}

\author{
${ }^{\# 1}$ Pramudana Ihsan, ${ }^{* 2}$ Eryna Rista Aulia \\ ${ }^{\# 1}$ English Education Lecturer, Faculty of Teacher Training and Education, \\ Universitas Muhammadiyah Surabaya, Indonesia \\ ${ }^{* 2}$ English Education Student, Faculty of Teacher Training and Education, \\ Universitas Muhammadiyah Surabaya, Indonesia
}

Corresponding Author Email: pramudanaihsan@fkip.um-surabaya.ac.id

\section{A B S T R A C T S}

Public speaking has become an integral part of many professions and is at the center of career development opportunities. Therefore, the change in the education system from offline to online has led to new ideas in the implementation of public speaking learning, namely by using Instagram as a learning medium for collecting assignments intended to introduce or sell English language skills which are usually called Edupreneurship. That way, it is hoped that not only carry out learning and collect assignments but also something is obtained. However, learning still prioritizes output. Therefore, in this study, we refer to the personal branding theory. The purpose of this study is to determine how effective the use of Instagram is as a medium to promote English speaking skills, to find out the followers' responses regarding the skills possessed by English students, and also what was gained from promoting English speaking skills. The subjects in this study were students in the $5^{\text {th }}$ semester. The number of respondents was 25 students. This research was conducted using data collection methods through Google forms. The results showed that Instagram provided effects and benefits to students, most of them stated that: (1) Students felt more confident in speaking English, (2) Students felt an improvement in their abilities, (3) Students felt more enthusiastic about positive comments and motivated by negative comments, (4) Students feel that Instagram is the right medium for promoting English speaking skills, (5) Students get input in the form of work.

\begin{tabular}{l}
\hline A R T I C L E I N F O \\
\hline Article History: \\
Received: October, 2020
\end{tabular}

Revised: November, 2020

Published: December, 2020

\author{
Keywords: \\ Public Speaking, \\ Instagram,
}

How to cite: Ihsan, P., \& Aulia, E. (2020). Instagram As Medium of Promoting English Speaking Skill: English Edupreneurship. Jo-ELT (Journal of English Language Teaching) Fakultas Pendidikan Bahasa \& Seni Prodi Pendidikan Bahasa Inggris IKIP, 7(2), 105-111. doi:https://doi.org/10.33394/jo-elt.v7i2.3180

\section{INTRODUCTION}

Public Speaking is the process of communicating information to an audience, usually done in front of a large audience such as in schools. In public speaking, the information is purposeful and intended to inform, influence, or entertain a group of listeners. This is usually done face-to-face, as well as lectures in public speaking courses at the University of Muhammadiyah Surabaya which were initially conducted face-to-face and since the Covid19 pandemic attacked Indonesia everything has changed, as well as the education system in Indonesia which was originally offline to online. This is certainly a big challenge for a number of educators to come up with ideas for creativity in online learning, which were initially debated about its effectiveness. However, with the adjustment and development of 
learning carried out by a number of educators, online learning becomes more fun and not monotonous like offline classes. It is different with the Public Speaking course, the University of Muhammadiyah Surabaya's English Education Study Program which uses Instagram as a learning medium and promoting English speaking skills. Promoting English speaking skills is a learning model that is expected to show students' English proficiency to everyone that was previously known only to himself, his lecturers and classmates. In addition, this learning model is intended to find out how the responses or comments given by the closest person, be it family, friends, neighbors, or followers are related to the English language skills possessed by English students. To maximize the promotion of English language skills, we use the Instagram platform as a medium. Because according to (Listiani, 2016) Instagram and its supporting features can be used as media in related activities in the learning process.

Instagram is a free photo and video sharing app available on Iphone and Android. Users can upload photos or videos and share them with their followers or with a group of friends. Users can also view, comment on, and like posts shared by their friends on Instagram. In this case, social media can be an alternative media for learning in the midst of the Covid-19 pandemic. In academia, Social Networking Sites (SNS) are considered very useful in language learning. Moreover, the popularity of social media is great and has an impact on students, because the intensity of students spending time on social media tends to be more. Therefore, this is a consideration to make Instagram a medium of learning in public speaking courses. Thus, teachers or educators can actively use Instagram to stay connected with students (Zhang, 2013).

The fundamental reason for using Instagram as a learning medium is that apart from the widespread use of social media, especially Instagram in various circles, there are also other factors such as wanting to show the ability of English education students to their closest people and followers or maybe it can also bring job opportunities. Even so, output remains a top priority. In addition, there are other considerations in the use of Instagram as a learning medium, namely Instagram can give students the authority to create their own digital content and publish it online through Instagram TV, for example, besides that it can stimulate student activeness, creativity, and self-confidence. Instagram allows for collaboration between students and educators on certain projects or tasks for learning purposes (Bexheti, 2014).

Students are ready for technological changes in learning (Manca \& Ranieri, 2013) especially during the current pandemic, where all education actors are forced to be ready to deal with technology. Therefore, choosing the right platform can be a benchmark for the success of a learning activity. Currently, the most popular SNS platforms are YouTube and Instagram. Especially in its use as a learning medium, this platform can have a positive impact, especially on language learning.

In language learning, besides focusing on improving students' speaking skills, it turns out that there are things that can be used from this. By using the Instagram platform as a medium, it is not only a matter of assignment and capacity building, but we can also sell English language skills through a model of promoting English speaking skills or what we are familiar with as "Edupreneurship", it is about essentially taking what you have in your head your knowledge, your skills, your expertise, your experiences - and turning it into a profitable learning product or program. Doing so increases your exposure, lead generation, sales, and authority positioning within your marketplace. In this study, we directed edupreneurship activities by using a model of promoting English speaking skills through the Instagram platform to bring out English language skills, with assignments in the form of videos which were then published through the Instagram TV (IG TV) feature, with the hope that some of the closest people such as family, friends, neighbors, and followers know the ability of English students that may not have been previously known. That way, allowing for comments 
or responses on this matter, so that there are job opportunities for English students from these learning models. Therefore, we are referring to the personal branding theory. According to Haroen (2014), personal branding is the process of shaping people's perceptions of aspects that a person has such as personality, abilities, or values and how they create positive perceptions from society that can be used as a marketing tool.

This study aims to analyze the use of Instagram as a learning medium or a medium for collecting assignments in the public speaking course, English Education Study Program, Muhammadiyah University of Surabaya. In the end, this study aims to determine the impact or effect that arises from using Instagram as a learning medium as well as collecting assignments specifically as a medium for promoting English speaking skills. Especially to find out the responses or comments from the closest people and followers to the skills possessed by English students or maybe there is input obtained from the assignment such as bringing in a job.

\section{RESEARCH METHOD}

This research was conducted by looking at the phenomenon of online learning during the covid-19 pandemic, apart from the use of several media to support the learning process. The author sees an opportunity to not only do that, but also benefit both psychologically and financially with a model that promotes English speaking skills with Instagram as the medium. Therefore, the authors conducted research through online surveys using a Google form. Then the authors processed the data using analytical descriptive methods that are supported by the results of qualitative data processing.

\section{Research Design}

This study uses a descriptive qualitative method designed to find out how effective Instagram is as a medium for promoting English speaking skills which is expected to lead to edupreneurship activities. Regarding data collection in this study, the author conducted it online through the Google Forms platform. In this case, the author uses a qualitative design to obtain data and present the results of this study.

\section{Population and Sample OR Subject}

This research was conducted on 5th semester students of the English Department Muhammadiyah University of Surabaya. This research was conducted on November 15, 2020. The subjects in this study were students who took public speaking courses, consisting of 25 people who were willing to be respondents from different classes of which 10 students from class A and 15 students from class B. This study only focuses on the output obtained by English students from promoting English speaking skills that allow Edupreneurship activities.

\section{Instruments}

In this study, the authors took several steps in data collection techniques. First, the author created a research instrument of 15 questions online through the Google Forms platform. Second, the authors predict the findings of these 15 questions and determine the focus of the study. Third, the authors share the Google Forms link with 25 respondents who are 5th semester students of English education. Then the data from the results of the answers of the respondents, the author notes, reflects on the findings and focus of the research that the author had previously predicted. Furthermore, the authors compile descriptive or narrative information related to the research focus, and proceed with drawing conclusions from the research results. 


\section{Data Analysis}

The data from the online survey results through the Google Forms are collected automatically. Then, the authors classify and verify a number of data from the arguments of each respondent according to the research findings that have been designed by the previous author. After that, the authors take notes based on data that had been arranged logically and systematically. The data analysis technique used is not only descriptive qualitative, but also descriptive argumentative, because the results of this study are based on the respondents' arguments and perspectives. In this case, the author only gets data from the respondents' arguments through Google Forms.

In data analysis, the authors combine the arguments of each respondent in each sub questions to find out how effective Instagram is as a medium for promoting English speaking skills and the input that students get. Finally, the authors draw conclusions.

\section{RESEARCH FINDINGS AND DISCUSSION Research Findings}

The results showed that Instagram gave effects and benefits to students, most of them stated that: (1) Students felt more confident in speaking English. That is why they prefer learning public speaking online compared to offline, about $80 \%$ of students prefer online classes and $20 \%$ of students like offline classes.

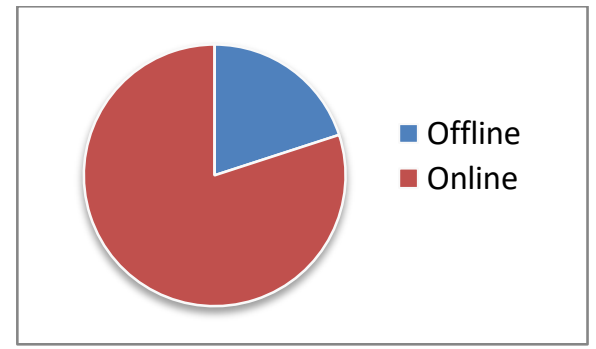

Figure 1. The Number of Students Who Choose Offline and Online Classes

They feel more confident because they are only dealing with gadgets and it makes them feel more comfortable. (2) Students felt that there was an increase in their abilities during learning public speaking online, about $60 \%$ of students felt that there was an increase in themselve, while $40 \%$ of students felt that there was no significant increase in their abilities.

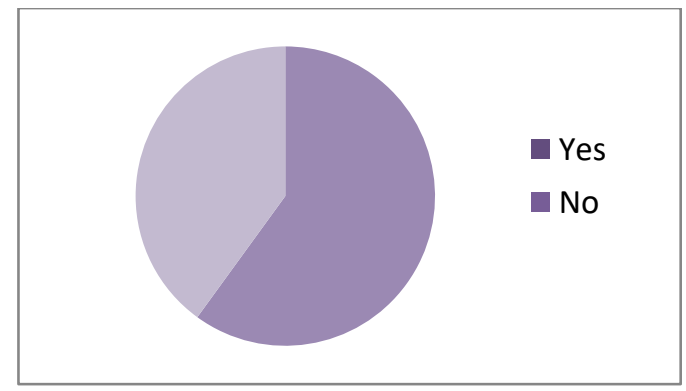

Figure 2. Data of Students Who Have Increased Abilities

They feel that with video assignments will be easier to judge their appearance and correct any mistakes or flaws in the next project or content. (3) Students feel more enthusiastic about positive comments and motivated by negative comments. Based on the data, about $80 \%$ of students are more enthusiastic about speaking English when they get positive comments from friends, family, and followers. Then, around $90 \%$ of students tend to feel more motivated to 
prove their best abilities, and so far they feel that their best performance is on sales promoting product content.

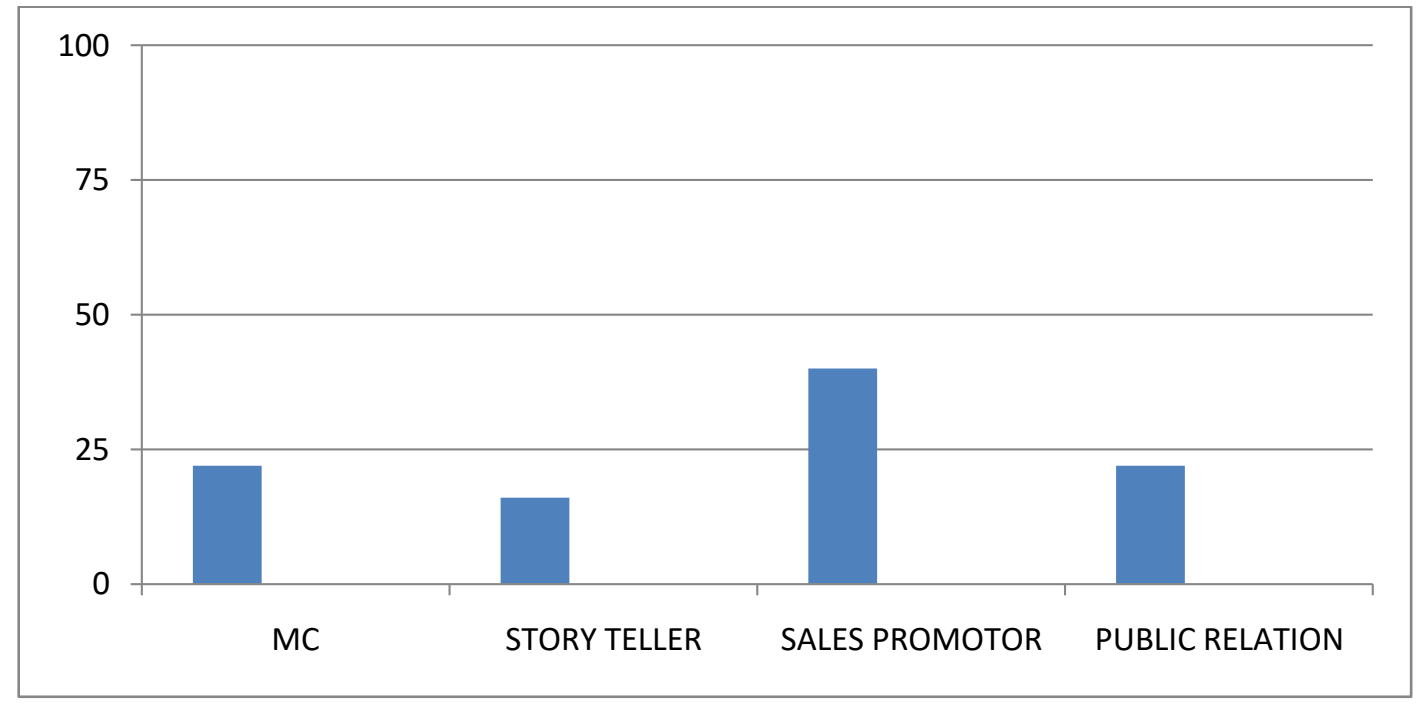

Figure 3. Accumulated Best Performance According to Respondents

(4) Students felt that Instagram was the right medium for promoting English speaking skills. All respondents thought that using Instagram as a medium for promoting English speaking skills was a good idea, and they thought it would work, because now many people use Instagram. In addition, they also feel that through promoting English speaking skills, finally many people know their abilities as English students, especially in speaking skills, so that there is a positive response from the closest people such as friends, family and followers who initially feel surprised by the abilities possessed by English students. Finally, some people really believe that they are English students and provide support to continue to improve their abilities. (5) Students get input in the form of work. In addition to the psychological effects felt by students from using Instagram as a medium for promoting English speaking skills, it turned out that there were other benefits felt by most students. Some of them feel that they have benefited financially from every video posting of a public speaking course assignment, because in addition to getting response and support from their closest people or followers, some of them have received job offers. Most are requested as an endorsment. Especially in a pandemic era like today, where buying and selling centers have switched to online sales. By looking at the English students' public speaking skills, finally some people made offers to help market their products. In addition, there are also those who get offers to teach private lessons, become birthday mc, and so on.

\section{Discussion}

Public speaking is one of the subjects that must be taken by all students of the English Language Education Study Program, Muhammadiyah University of Surabaya. This course has a weight of 2 credits with a total of 16 meetings online. The purpose of this course is to improve public speaking skills.

The Instagram platform was chosen as a learning medium as well as a medium for collecting assignments for this course, especially for semester 5 students. In this study, the authors wanted to know the effectiveness and input of using Instagram as a medium for promoting English speaking skills, in which each student got an assignment. Individuals to make videos acting out some professions related to public speaking and speaking English of course. Then, it is published through a personal Instagram account to be precise on the 
Instagram Tv (IG TV) feature by including a predetermined hashtag and marking the lecturer Instagram account of the course. There are 10 video content that must be published every week, starting from the Master of Ceremony (MC), Story Teller, Sales Promoting Product, Public Relations Officer, TV Host, Motivator, News Anchor, Interviewer, Political Campaigner, and Tour Guide. Regarding video content, students cannot vote. They should try to do all of these professions. Then for the assessment, apart from being obtained from the lecturer, students must also rate each other's video of their classmates through an assessment sheet that has been designed by the lecturer. In addition to receiving assessments from lecturers and classmates, this study focuses on the English Promoting Skill, in which it is hoped that there will be comments from followers or closest people regarding the abilities possessed by English students. so that it can bring in job offers from videos that have been published. So with this will make English Edupreneurship, based on the theory of personal branding. It can be interpreted as a practice to promote oneself, career, and achievement as a brand. So it can be said that personal branding is a way of promoting yourself, in this case Instagram as the medium.

In previous research related to Exploring Students' Learning Strategies in Speaking Performance, it has been found that the strategies that are often used by English students are memory strategies, metacognitive strategies, social strategies, and so on. However, in this study we want to prove that there are other learning strategies that can be used, namely by utilizing the abilities possessed by English students. That way, we are more focused on selling the abilities of English students by promoting English speaking skills.

\section{CONCLUSION}

Based on the results of data analysis, it can be concluded that the use of Instagram as a medium for promoting English speaking skills in the public speaking course is successful. Because in accordance with what was expected beforehand. So it can be said that Instagram is the right medium for promoting English speaking skills, because it has succeeded in making the closest people and followers know the abilities of English students. Therefore, with this kind of learning model not only focuses on improving student abilities, but also there are inputs that can be taken by selling students' English skills, which indirectly has an Edupreneurship process. This is evidenced by the job offers received by several students of the English language education study program, University of Muhammadiyah Surabaya.

\section{ACKNOWLEDGEMENT}

Alhamdulillahi rabbil 'alamin, the author would like to thank Allah SWT for his blessings and health favors for completing a paper entitled "Instagram as a Medium of Promoting English Speaking Skill: English Edupreneurship" in preparing this paper, many parties have provided motivation, advice, and support the author. In this valuable opportunity, the author intends to express gratitude and appreciation to all parties. First, the author's deepest appreciation goes to both people for their endless love, prayers, and support.

Finally, I would like to thank all those who have played an important role in the success of this paper which is still far from perfect, but it is hoped that it can be useful not only for researchers, but also for readers. For this reason, constructive criticism and suggestions are welcome.

\section{REFERENCES}

Bexheti. L. (2014, March 12). An Analysis of Social Media Usage in Teaching and Learning: The Case of SEEU. Retrieved January, 18, 2020, from https://www.researchgate.net/profile/Betim_Cico2/publication/316911404_An_Analysi s_of_Social_Media_Usage_in_Teaching_and_Learning_The_Case_of_SEEU/links/591 
76795a6fdcc963e85624b/An-Analysis-of-Social-Media-Usage-in-Teaching-andLearning-The-Case-of-SEEU.pdf

Bigbanktheories. (2016, October 15). Contoh Acknowledgement Skripsi dalam Bahasa Inggris Terbaru. Retrieved February, 5, 2020, from https://www.bigbanktheories.com/contoh-acknowledgement-skripsi-dalam-bahasainggris-terbaru/.

Haroen, D. (2014). Personal Branding: Kunci Kesuksesan Berkiprah di Dunia Politik. Jakarta: PT. Gramedia Pustaka Utama.

Help.instagram. (2020, January 5). What is Instagram?. Retrieved January, 10, 2020, from https://help.instagram.com/424737657584573.

Jagoanhosting. (2020, April 7). Personal Branding: Strategi Membangun Citra Diri yang Kuat. Retrieved May, 12, 2020, from https://www.jagoanhosting.com/blog/membangun-personal-branding/.

Listiani. G. (2016, July 16). The Effectiveness of Instagram Writing Compared to Teacher Centered Writing to Teach Recount Text to Students With High and Low Motivation. Retrieved May, 12, 2020, from https://media.neliti.com/media/publications/326927-theeffectiveness-of-instagram-writing-c-774b7354.pdf.

Manca. S., \& Ranieri. M. (2013, March 5). Is It a Tool Suitable For Learning? A Critical Review of The Literature on Facebook as a Technology-Enhanced Learning Environment. Journal of Computer Assisted Learning. Retrieved February, 15, 2020, from https://onlinelibrary.wiley.com/doi/abs/10.1111/jcal.12007.

Sarahcordiner. (2020, January 12). What is Edupreneurship \& How Can it Make You Money?. Retrieved February, 15, 2020, from https://sarahcordiner.com/what-isedupreneurship-how-can-it-make-2/.

Sesriyani, L., \& Sukmawati, N. (2019). Analisis Penggunaan Instagram Sebagai Media Pembelajaran Bahasa Inggris Pada Program Studi Pendidikan Ekonomi. EDUKA: Jurnal Pendidikan, Hukum, dan Bisnis.

Study.com. (2014, May 14). What is Public Speaking and Why Do I Need to do it?. Retrieved May, 12, 2020 from https://study.com/academy/lesson/what-is-public-speaking-andwhy-do-I-need-it.html.

Wael, A., Asnur, M., \& Ibrahim, I. (2018). Exploring Students' Learning Strategies in Speaking Performance. International Journal of Language Education, 65-71.

Zhang, L. (2013). Mobile Phone Technology Engagement in EFL Classroom. Proceedings of the 2013 International Conference on Software Engineering and Computer Science, 171-174. https://doi.org/10.2991/icsecs-13.2013.37. 